\title{
Implementasi Program Jaminan Kesehatan Masyarakat (Jamkesmas) di Kabupaten Bantul
}

\author{
Marita Ahdiyana dan Wasiti \\ E-mail: marita_ahdiyana@yahoo.com
}

This research studies about implementation of Jamkesmas program in Bantul Regency to know how reality of implementation and problems surfaced in its implementation. This qualitative research results is that process of target group establishment has followed the procedure even though in the field it is constrained by not updated data. Bantul Regency has done social security (Jamkesos), childbirth security (Jampersal), life saving and the use of SKM. In mechanism how to get service from PPK, significant constrain is not found because of clear SOP. Mechanism and process of PPK claim verification has been done in accordance with provision even though it is often late. In the aspect of organization implementers' capability, they are reliable because they have been through training. Coordination between program implementers and 11 hospitals in Bantul is done once in every two months. Meanwhile, infrastructure which supports implementation is adequate even though there is no specific fund. The outcome of the policy, in term of financial holding, is transparent and accountable even though it is still constrained by late claim payment. Improvement of the poor people's access to health services is also caused by the presence of other programs beside Jamkesmas.

Keywords: implementation, Jamkesmas, and health service provider (PPK)

Undang-Undang Dasar 1945 Pasal 28 dan Undang-Undang No. 23 Tahun 1992 tentang kesehatan menetapkan bahwa setiap orang berhak mendapatkan pelayanan kesehatan. Untuk menjamin akses penduduk miskin terhadap pelayanan kesehatan sebagaimana diamanatkan dalam UUD 1945 tersebut, pemerintah telah berupaya untuk membuat kebijakan melalui Program Jaminan Kesehatan Masyarakat (Jamkesmas). Program Jamkesmas dilaksanakan di hampir semua rumah sakit pemerintah di Indonesia, salah satunya di Rumah Sakit Panembahan Senopati Kabupaten Bantul. Pelaksanaan Program Jamkesmas di Kabupaten Bantul berdasarkan pada Keputusan Menteri Kesehatan RI No. 125/Menkes/SK/II/ Tahun 2008 tentang Pedoman Penyelenggaraan Program Kesehatan Masyarakat Tahun 2008, tanggal 6 Februari Tahun 2008 dan Keputusan Bupati Bantul Nomor 168 C Tahun 2007 tentang Penetapan Jumlah Masyarakat Miskin sebagai Peserta Program Jamkesmas Kabupaten Bantul Tahun 2008, sehingga diharapkan pelaksanaan program tersebut sudah sesuai dengan tujuan utamanya dan tepat sasaran. Namun demikian belum diketahui bagaimana pelaksanaan program Jamkesmas tersebut, sehingga perlu dilakukan penelitian untuk memperoleh gambaran pelaksanaan program Jamkesmas di Kabupaten Bantul. 
Dalam pelaksanaannya, bagi masyarakat miskin yang membutuhkan harus melengkapi persyaratan dan mengikuti prosedur yang telah ditentukan sehingga ada kesan rumit dan membingungkan bagi masyarakat miskin yang sebagian berpendidikan rendah. Meskipun telah ada program Jamkesmas, warga miskin yang sedang sakit masih saja terabaikan dan masih harus membayar biaya perawatan di rumah sakit, bahkan ditemukan adanya penolakan terhadap pasien Jamkesmas. Sehingga di Bekasi pasien yang memiliki kartu Jamkesmas tetap dipungut bayaran (Kompas, 25 Februari 2009).

Hasil riset yang dilakukan Indonesia Corruption Watch (ICW) terhadap program Jamkesmas (Kompas, 3 Maret 2009), menunjukkan bahwa ada beberapa permasalahan yang ada dalam pelaksanaan program yaitu data peserta masih belum akurat, sosialisasi belum optimal, dan adanya pungutan untuk mendapatkan kartu. Selain itu, permasalahan lain adalah adanya peserta yang tidak menggunakan kartu ketika berobat, adanya pasien Jamkesmas yang mengeluarkan biaya, dan masih buruknya kualitas pelayanan pasien Jamkesmas. Lebih lanjut dikemukakan dari 868 responden terdaftar yang dipilih secara acak itu, 12,4 persen tidak memiliki kartu. Ada pula 3 persen meninggal dunia, pindah alamat 3,1 persen, nama tidak dikenal 9,9 persen serta sebanyak 22,1 persen responden tidak dapat verifikasi. Temuan ini jelas menunjukkan tidak ada pembaruan data dari pemerintah daerah. Seharusnya kuota peserta yang telah meninggal atau pindah alamat bisa dipindahalihkan kepada masyarakat miskin lainnya yang membutuhkan. Sosialisasi Jamkesmas dinilai belum optimal, 25,8 persen dari responden tidak mengetahui apa itu Jamkesmas. Sehingga ICW menuntut adanya perbaikan oleh Departemen Kesehatan dalam penyelenggaraan pelayanan kesehatan bagi masyarakat miskin, termasuk peningkatan pengawasan terhadap kinerja pemerintah daerah, rumah sakit, dan puskesmas.

Evaluasi pelaksanaan program Jamkesmas yang dilakukan oleh Badan Perencanaan Pembangunan Daerah (Bappeda) di Kabupaten Gresik menunjukkan, bahwa banyak kasus salah sasaran dalam pelaksanaan program jamkesmas, diantaranya amburadulnya pendataan warga yang berhak menerima program tersebut, sehingga banyak warga miskin yang seharusnya mendapatkan jatah pengobatan gratis tidak mendapatkan, sedangkan warga yang masuk kategori mampu malah tercatat sebagai penerima program jamkesmas. Bahkan ada warga yang berasal dari luar wilayah Gresik tercatat sebagai penerima program di kabupaten tersebut (Jawa Pos, 17 Desember 2009).

Penelitian implementasi program Jamkesmas di Kabupaten Karanganyar dari perspektif hukum telah dilakukan oleh Nugraha (2008). Dari sisi manajemen administrasi pelayanan kesehatan, juga telah dilakukan penelitian oleh Ernawati Carisma (2008). Namun 
demikian, perlu dilakukan penelitian tentang implementasi program Jamkesmas dari perspektif kebijakan publik di Kabupaten Bantul, di mana peneliti sering berinteraksi dengan para peserta program Jamkesmas.

Ada berbagai pendekatan implementasi kebijakan menurut para ahli. Peter deLeon dan Linda deLeon (2001) dalam Nugroho (2008:437- 438) mengelompokkan pendekatanpendekatan dalam implementasi kebijakan publik menjadi tiga generasi yaitu: generasi pertama sekitar tahun 1970-an, implementasi kebijakan berhimpitan dengan studi pengambilan keputusan di sektor publik, generasi kedua tahun 1980-an, implementasi kebijakan yang bersifat top down, dan generasi ketiga tahun 1990-an, variabel perilaku aktor pelaksana implementasi kebijakan lebih menentukan keberhasilan implementasi kebijakan. Sehingga dari tiga generasi tersebut, terdapat berbagai macam teori implementasi, seperti dikemukakan oleh George C. Edwards III (1980), Merilee S. Grindle (1980), Daniel A. Mazmanian dan Paul A. Sabatier (1983), Van Meter dan Van Horn (1975), Elmore dkk (1979), Hogwood dan Gunn (1978), Goggin (1990), Nakamura dan Smallwood (1980), serta model jaringan (1997).

Dengan mendasarkan pada teori dan konsep beberapa ahli di atas, maka yang dimaksud dengan implementasi program Jamkesmas di Kabupaten Bantul adalah proses pelaksanaan keputusan kebijaksanaan dasar, yang dibuat oleh eksekutif berbentuk berbagai peraturan dan keputusan yang penting dalam mengatur penyelenggaraan dan pelaksanaan program Jamkesmas di Kabupaten Bantul. Agar tidak terjadi perluasan dalam penelitian ini dan untuk memudahkan dalam pencarian data maka penulis memfokuskan penelitian pada (1) mekanisme prosedur dan proses penetapan kelompok sasaran sebagai peserta program Jamkesmas, (2) mekanisme peserta program Jamkesmas mendapatkan pelayanan dari pemberi layanan kesehatan (PPK) baik rumah sakit maupun Puskesmas, (3) mekanisme dan proses verifikasi klaim PPK, (4) kemampuan organisasi pelaksana kebijakan, (5) pencapaian hasil akhir (outcomes) kebijakan, (6) penyelenggaraan keuangan yang transparan dan akuntabel dalam program, dan (7) permasalahan-permasalahan yang ada dalam implementasi kebijakan.

\section{Metode}

Metode penelitian yang digunakan adalah kualitatif deskriptif. Tempat penelitian adalah Kabupaten Bantul. Teknik pengumpulan data menggunakan observasi, dokumentasi, dan wawancara mendalam. Teknik analisis data yang digunakan adalah metode analisis kualitatif.

\section{Hasil dan Pembahasan}

Pelaksanaan Program Jamkesmas di Kabupaten Bantul berdasarkan pada Keputusan Menteri Kesehatan RI No. 125/Menkes/SK/II/2008 tentang Pedoman Penyelenggaraan Program Kesehatan Masyarakat Tahun 2008 tanggal 6 Februari 2008 dan Keputusan Bupati 
Bantul Nomor 168 C Tahun 2007 tentang Penetapan Jumlah Masyarakat Miskin sebagai Peserta Program Jamkesmas Kabupaten Bantul Tahun 2008. Tujuan Penyelenggaraan Program Jamkesmas secara umum adalah untuk memberikan akselerasi dalam peningkatan akses dan mutu pelayanan kesehatan terhadap seluruh masyarakat miskin dan tidak mampu agar tercapai derajat kesehatan masyarakat yang optimal secara efektif dan efisien. Secara khusus program Jamkesmas ditujukan untuk meningkatkan cakupan masyarakat miskin dan tidak mampu guna mendapat pelayanan kesehatan di Puskesmas serta jaringannya dan di Rumah Sakit. Melalui program Jamkesmas pula diharapkan akan terjadi proses penyelenggaraan pengelolaan keuangan yang transparan dan akuntabel yang pada akhirnya akan berdampak kepada peningkatan kualitas pelayanan kesehatan bagi masyarakat miskin.

Program Jamkesmas berbentuk bantuan sosial untuk pelayanan kesehatan bagi masyarakat miskin dan tidak mampu dan diselenggarakan secara nasional agar terjadi subsidi silang dalam rangka mewujudkan pelayanan kesehatan yang menyeluruh bagi masyarakat miskin. Kegiatan yang dilaksanakan dalam Program Jamkesmas meliputi (1) pembinaan, pengembangan pembiayaan dan jaminan pemeliharaan kesehatan, (2) pelayanan kesehatan rujukan bagi masyarakat miskin, dan (3) pelayanan kesehatan dasar bagi masyarakat miskin.

Kepesertaan Program Jamkesmas Peserta program Jamkesmas adalah setiap orang miskin dan tidak mampu selanjutnya disebut peserta JAMKESMAS, yang terdaftar dan memiliki kartu dan berhak mendapatkan pelayanan kesehatan. Selanjutnya pada tahun 2010, sasaran program Jamkesmas diperluas kepada tiga kelompok sasaran baru yaitu orang miskin baru akibat tertimpa musibah bencana, orang miskin penghuni Lembaga Pemasyarakatan (Lapas) dan di Rumah Tahanan (Rutan), orang-orang tua miskin yang tinggal di Panti Sosial, anak terlantar dan anak-anak yatim piatu yang tinggal di panti-panti asuhan. Jaminan kesehatan pada kelompok tersebut ditetapkan melalui Peraturan Menteri Kesehatan RI No.1185-SKMenkes-XII-2009 tertanggal 13 Desember 2009 Tentang Penetapan orang miskin di LapasRutan, Orang-orang tua miskin, anak terlantar dan yatim piatu di panti-panti sosial, serta orang miskin akibat bencana dijamin oleh Jamkesmas.

Sasaran Jamkesmas di setiap Kabupaten/Kota belum dianggap sah apabila Bupati/Walikota belum menetapkan peserta Jamkesmas Kabupaten/Kota dalam satuan jiwa berisi nomor, nama dan alamat peserta dengan bentuk Keputusan Bupati/Walikota. Daftar peserta Jamkesmas dalam keputusan Bupati/Walikota dikirim kepada PT. Askes (Persero) Provinsi DIY diserahkan ke Kantor PT. Askes (Persero) Cabang Utama Yogyakarta untuk diterbitkan kartunya dan didistribusikan. 


\section{Mekanisme prosedur dan proses penetapan kelompok sasaran peserta program Jamkesmas}

Penetapan indikator keluarga miskin di Kabupaten Bantul didasarkan pada Peraturan Bupati No. 21A tahun 2007, antara lain penghasilan tidak lebih Rp 800 ribu dalam satu bulan, seluruh anggota keluarga tidak mampu makan minimal dua kali sehari, tempat tinggal atau rumah berlantai tanah, berdinding bambu atau beratap rumbia. Berdasarkan kriteria tersebut, petugas BKKPP dan KB melakukan pendataan menggunakan formulir yang akan diskor untuk menentukan status keluarga apakah masuk dalam kategori tidak miskin (TM), rawan miskin (RM), miskin (M) atau miskin sekali (MS). Penerima Jamkesmas adalah keluarga yang dikategorikan M dan MS. Berdasarkan data BPS tahun 2008, jumlah penerima Jamkesmas di Kabupaten Bantul mencapai 222.987 jiwa, sama dengan jumlah penerima tahun 2009 dan 2010.

Indikator kelompok sasaran telah dibuat tetapi dalam pelaksanaannya di lapangan masih terdapat berbagai permasalahan. Masih ada warga miskin yang tidak mendapatkan Jamkesmas sementara warga yang lebih mampu mendapatkannya. Hal ini disebabkan oleh petugas yang tidak turun langsung untuk mendata warga miskin. Petugas mendapatkan data warga miskin dengan menanyai aparatur desa sehingga memungkinkan pemilihan calon peserta Jamkesmas berdasarkan kedekatan personal. Selain itu, kriteria warga miskin dilematis dengan keadaan papan Kabupaten Bantul. Pasca gempa tahun 2006, banyak warga miskin yang menerima bantuan rumah permanen berlantai keramik. Aspek papan dalam indikator penentuan sasaran menjadi tidak valid.

Setelah penentuan sasaran selesai, mekanisme penerbitan dan pendistribusian kartu peserta Jamskesmas dilakukan oleh PT. Askes (Persero). Mekanisme ini meliputi proses registrasi peserta, penerbitan dan pendistribusian kartu. Bupati membuat SK penerima Jamkesmas berdasarkan sasaran kuota kabupaten/kota. Daftar peserta Jamkesmas dalam keputusan Bupati Bantul dikirim kepada PT. Askes (Persero) Cabang Utama Yogyakarta untuk diterbitkan kartunya dan didistribusikan. Penerbitan Kartu Peserta Jamkesmas oleh PT. Askes (Persero) tersebut dimulai dengan proses pencetakan blanko, entri data, penerbitan dan distribusi kartu sampai ke peserta. PT. Askes (Persero) AAM Kabupaten Bantul bertugas mengecek keabsahan data di 11 rumah sakit di Kabupaten Bantul yang menerima Jamkesmas.

Masalah mekanisme penerbitan dan pendistribusian kartu peserta Jamskesmas yang ditemui di lapangan adalah adanya penduduk yang sudah meninggal tetapi masih terdaftar sebagai peserta Jamkesmas. Penyebabnya adalah pemutakhiran data yang dilakukan Kabupaten Bantul setiap tahun dan dikirim ke Departemen Kesehatan RI tidak menjadi acuan Jamkesmas tahun berikutnya. Data yang digunakan mengacu pada BPS sehingga walaupun 
implementasi Jamkesmas telah mengacu pada mekanisme yang berlaku, masih ada warga yang sudah meninggal terdaftar sebagai peserta Jamkesmas.

Selain peserta program Jamkesmas dari kelompok penduduk keluarga miskin, Pengelola program Jamksesmas di Kabupaten Bantul juga memasukan kelompok lain seperti gelandangan, pengemis, anak terlantar, masyarakat miskin yang tidak memiliki identitas, pasien sakit jiwa kronis dan penyakit kusta. Pendataan kategori penduduk ini dilakukan oleh Dinas Sosial Kabupaten/Kota dan PT. Askes (Persero) dengan kerja sama pihak ketiga apabila dibutuhkan. Nama-nama yang pendataannya dilakukan oleh Dinas Sosial Kab/Kota ditetapkan oleh Dinas Sosial Kab/Kota. Sedangkan nama-nama hasil pendataan PT. Askes (Persero) setempat dengan pihak Jamkesmas Pusat ditetapkan dengan tembusan Tim Pengelola Jamkesmas Kab/Kota.

Keberadaan warga lain di luar masyarakat miskin ini memungkinkan nama calon penerima Jamkesmas melebihi kuota daerah. Di dalam Pedoman Pelaksanaan Jamkesmas (2008) disebutkan bahwa apabila kuota Jamkesmas melebihi alokasinya, maka masyarakat miskin menjadi tanggung jawab pemerintah daerah setempat. Pada tahun 2012 Pemerintah Kabupaten Bantul akan mengadakan Jamkesda. Program Jaminan persalinan (Jampersal) juga telah dilaksanakan di Bantul bagi keluarga miskin. Kabupaten Bantul juga merencanakan pelaksanaan program Jaminan Kesehatan Daerah (Jamkesda) dan program live saving atau program untuk masyarakat miskin di Bantul yang menderita lima macam penyakit kronis, namun tidak masuk dalam program Jamkesmas maupun Jamkesos dapat diakses masyarakat dengan surat keterangan miskin (SKM) dari RT/RW/Kelurahan.

Dari pembahasan tersebut, di Kabupaten Bantul mekanisme bagi peserta program dari kelompok lain di luar masyarakat miskin sudah dilakukan mengacu pada ketentuan yang berlaku. Sedangkan untuk jaminan bagi masyarakat di luar program Jamkesmas, Kabupaten Bantul melaksanakan Jamkesos dengan dana dari pemerintah DIY, Jampersal, dan baru akan melaksanakan program Jamkesda pada tahun 2012, serta program live saving untuk penderita lima penyakit kronis yang tidak menjadi peserta program kesehatan lain.

\section{Mekanisme peserta Jamkesmas mendapatkan pelayanan dari Pemberi Pelayanan Kesehatan (PPK)}

Pelayanan yang diberikan dibagi menjadi empat kategori, yaitu: Rawat Jalan Tingkat Pertama (RJTP), Rawat Inap Tingkat Pertama (RITP), Rawat Jalan Tingkat Lanjutan (RJTL), dan Gawat Darurat. Pelayanan kesehatan dilaksanakan secara berjenjang berdasarkan rujukan. Pelayanan rawat jalan tingkat pertama diberikan di Puskesmas dan jaringannya (Pustu). Pelayanan rawat jalan lanjutan diberikan di BKMM/BBKPM/BKPM/ BP4/BKIM dan Rumah 
Sakit. Pelayanan rawat inap diberikan di Puskesmas Perawatan dan ruang rawat inap kelas III (tiga) di RS Pemerintah termasuk RS Khusus, RS TNI/POLRI dan RS Swasta yang melaksanakan program Jamkesmas.

PPK yang memberikan pelayanan Jamkesmas telah membuat Perjanjian Kerjasama (PKS) dengan Dinas Kesehatan Kabupaten Bantul, yang diketahui Kepala Dinas Kesehatan Provinsi DIY. Namun demikian semua PPK wajib memberikan pelayanan gawat darurat (emergency) pada peserta program Jamkesmas meskipun tidak memiliki perjanjian kerjasama sebagai bagian dari fungsi sosial PPK. Selanjutnya segera setelah penanganan darurat pasien dapat dirujuk ke RS yang memiliki perjanjian kerjasama. Apabila dalam proses pelayanan terdapat kondisi dengan diagnosa penyakit/tindakan yang belum tercantum dalam paket dan tarif yang ditetapkan dalam aturan pelayanan Jamkesmas maka tim RS (Komite medik RS) membuat penyetaraan dengan tarif melalui Keputusan Direktur RS/Kepala Balai, kemudian disampaikan ke Sekretariat Jamkesmas Pusat untuk dapat dipertimbangkan dan diberlakukan secara nasional. Pelayanan Keluarga Berencana (KB) juga dapat didapat peserta Jamskesmas.

Untuk mendapatkan perawatan di Puskesmas (PPK I), peserta Jamkesmas perlu membawa kartu Jamkesmas, Kartu Keluarga (KK), dan Kartu Tanpa Penduduk (KTP) sedangkan untuk di Rumah Sakit (PPK II/III) peserta Jamkesmas juga harus membawa surat rujukan dari Puskesmas dan Surat Keabsahan Peserta (SKP) yang diterbitkan oleh PT. Askes (Persero).

Di Kabupaten Bantul mekanisme peserta Jamkesmas mendapatkan pelayanan dari PPK telah terlaksana sesuai prosedur. Cara mendapatkan pelayananan dari PPK ini mudah apabila masyarakat telah mengikuti prosedur tersebut.

\section{Mekanisme mekanisme dan proses verifikasi klaim PPK}

Verifikasi dalam penyelenggaraan Jamkesmas merupakan sebuah kegiatan penilaian administrasi terhadap klaim yang diajukan oleh PPK, seperti rumah sakit dan puskesmas. Verifikasi bertujuan untuk meningkatkan efisiensi dan mutu pelayanan Jamkesmas atau yang dalam istilah teknis dinamakan kendali biaya dan kendali mutu.

Pelaksana Verifikasi di Puskesmas oleh Tim Pengelola Jamkesmas Kabupaten Bantul, sesuai dengan petunjuk teknis Jamkesmas di Puskesmas dan Jaringannya tahun 2008 yang dikeluarkan oleh Direktorat Jendral Bina Kesehatan Masyarakat Depkes RI. Klaim dari Puskesmas dilakukan dengan mengajukan permohonan ke rumah sakit setempat yaitu RS Panembahan Senopati, disertai dengan kartu klaim atau kartu bukti penjaminan. Klaim tidak akan dapat dipenuhi jika tidak ada kartu bukti penjaminan. 
Sementara untuk Verifikasi di RS dilaksanakan dengan melalui mekanisme sebagai berikut: (1) Verifikasi keabsahan peserta Jamkesmas menjadi tanggung jawab PT. Askes (Persero) yang dilaksanakan oleh petugas PT. Askes (Persero) dengan mengeluarkan surat keabsahan peserta (SKP), (2) Verifikasi pelayanan dan keuangan dilaksanakan oleh petugas khusus yang independen (Verifikator Independen) dengan menggunakan pedoman yang ditetapkan oleh Tim Pengelola Jamkesmas Pusat, dan (3) Entry data terkait pelayanan peserta Jamkesmas di RS/BKMM menjadi tanggung jawab dan fungsi petugas klaim RS/BKMM. Hasil entry data tersebut diserahkan kepada verifikator independen segera dilakukan verifikasi.

Berkaitan dengan kegiatan verifikasi, Menteri Kesehatan telah mengeluarkan Surat Keputusan Menteri Kesehatan No. 124/ Menkes/SKN/2008 tentang Tenaga Pelaksana Verifikator Klaim Program Jamkesmas. Sebelumnya para tenaga verifikator juga harus melalui pelatihan terlebih dahulu.

Di Kabupaten Bantul, petugas yang bertugas melakukan verifikasi berasal dari petugas di PT Askes (Persero) AAM Bantul. Tenaga verifikasi tersebut sebelum melaksanakan proram sudah melalui program pelatihan tenaga verifikator yang dilakukan oleh Departemen Kesehatan Pusat. Namun hanya ada empat tenaga verifikator yang harus mengecek keabsahan peserta melalui surat keabsahan peserta ke berbagai rumah sakit yang menyelenggarakan layanan pogram Jamkesmas. Sementara itu tidak tersedia dana tambahan diluar jam kerja sehingga kadang tugas dilaksanakan sampai malam hari. Sehingga petugas verifikator dari PT Askes (Persero) AAM Bantul merasa terbebani karena mereka juga tetap menjalankan tugas di luar program Jamkesmas.

Dari pembahasan tersebut, mekanisme dan verifikasi klaim baik dari puskesmas maupun dari rumah sakit sudah dilaksanakan sesuai dengan ketentuan yang berlaku, walaupun masih ada kendala berupa keterbatasan jumlah tenaga verifikator dan insentif dana bagi tugas tersebut yang tidak dianggarkan tersendiri.

\section{Kemampuan organisasi pelaksana kebijakan}

Kemampuan organisasi pelaksana kegiatan dilihat dari tiga hal, yaitu Sumber Daya Manusia (SDM), koordinasi dan komunikasi di antara pelaksana kebijakan, dan sarana dan prasarana penunjang pelaksanaan kebijakan.

Pertama, kemampuan organisasi pelaksana Jamkesmas dilihat dari kemampuan SDM rumah sakit dan PT. Askes (Persero). Pelatihan juga telah diberikan kepada SDM Rumah Sakit dalam melakukan pelayanan termasuk di RS Panembahan Senopati. Dari sisi tenaga medis, saat ini RS Panembahan Senopati didukung oleh dokter-dokter yang memiliki spesialisasi di bidangnya masing-masing. RS tersebut juga didukung oleh peralatan-peralatan modern. 
Walaupun untuk menangani penyakit tertentu, masih harus di rujuk ke rumah sakit yang lebih lengkap peralatannya seperti ke RSUP Dr. Sardjito.

Pelayanan Jamkesmas di RS dilaksanakan sesuai dengan standar yang telah ditetapkan. Masalah yang muncul hanya pada penggantian perangkat lunak (software) yang digunakan dalam memberikan pelayanan. Pada tahun 2011, petugas rumah sakit baru saja menguasai sistem perangkat lunak yang lama dalam pengajuan klaim PPK kepada Penjamin Pembiayaan di pusat, sistemnya kemudian berganti sehingga harus belajar kembali. Selain rumah sakit, organisasi yang berperan adalah PT. Askes (Persero) yang juga telah melaksanakan pelatihan khususnya untuk tim verifikasi.

Keberadaan Jamkesmas meningkatkan kapasitas kelembagaan. Hal ini sebagaimana dijelaskan oleh Kepala Bagian Keuangan merangkap koordinator Jamkesmas RS Panembahan Senopati, Andriyandono, MM. Diungkapkan bahwa dari sisi efisiensi, program Jamkesmas mampu membuat rumah sakit di daerah, khususnya RSUD Panembahan Senopati Bantul, terdorong untuk bekerja lebih efisien karena program ini sudah terpola dan terstandardisasi, lebih efektif dalam bekerja sebab sudah ada standar kerja, serta dapat menjadi ajang promosi rumah sakit, selain itu pendapatan RS juga meningkat karena warga miskin tidak ragu-ragu datang ke rumah sakit, dan RS juga tidak khawatir terhadap kepastian pembayaran sebab sudah ada yang menjamin.

Dari pembahasan tersebut, sumber daya manusia pelaksana program Jamkesmas di Kabupaten Bantul terutama di RS Panembahan Senopati memiliki kemampuan yang dibutuhkan untuk melakukan tugasnya karena sudah melalui proses pelatihan sebelumnya, hal tersebut juga berlaku bagi sumber daya manusia di instansi terkait misalnya PT Askes (Persero) AAM Bantul.

Kedua, kemampuan pelaksana dilihat dari koordinasi dan komunikasi di antara para pelaksana kebijakan. Dalam rangka koordinasi implementasi program Jamkesmas di Kabupaten Bantul, telah dikeluarkan Surat Keputusan Bupati Bantul Nomor 252 tentang Pembentukan Tim Koordinasi Program Jamkesmas Kabupaten Bantul Tahun 2009 dan masih berlaku hingga saat ini. Tim tersebut mempunyai tugas (1) menetapkan arah kebijakan koordinasi dan sinkronisasi program Jamkesmas Kabupaten Bantul, (2) melakukan pembinaan dan pengendalian Program Jamkesmas Kabupaten Bantul, (3) melaksanakan pertemuan review/evaluasi secara berkala sesuai kebutuhan, dan (4) menyelesaikan permasalahan Jamkesmas yang menyangkut lintas sektor di Kabupaten Bantul.

Dalam pelaksanaan, setiap 2 bulan sekali diselenggarakan rapat koordinasi penyelenggaraan program Jamkesmas yang dilakukan oleh tim pengelola Jamkesmas dengan 
11 rumah sakit, dengan koordinator Dinas Kesehatan Kabupaten Bantul. Permasalahannya hanya ada empat tenaga verifikator yang harus mengecek keabsahan peserta ke berbagai rumah sakit, sementara tidak tersedia dana tambahan diluar jam kerja sehingga kadang tugas dilaksanakan sampai malam hari. Pihak PT Askes (Persero) AAM Bantul merasa terbebani karena mereka juga tetap menjalankan tugas di luar program Jamkesmas. Namun demikian karena adanya forum pertemuan tersebut sehingga menyebabkan mereka memiliki kontakkontak person di rumah sakit sehingga hal tersebut dapat memudahkan dalam berkomunikasi terutama ketika harus datang ke berbagai rumah sakit untuk melakukan cek keabsahan peserta.

Dari pembahasan tersebut, koordinasi antar pelaksana dan pengelola program sudah dilakukan, walaupun hanya dua bulan sekali. Dukungan dana khusus untuk kerja tambahan di luar jam kerja karena program tersebut juga tidak ada. Namun demikian sewaktu-waktu petugas verifikasi juga sudah melakukan koordinasi dengan petugas rumah sakit atau puskesmas untuk mengecek surat keabsahan peserta.

Ketiga, keberadaan sarana dan prasarana penunjang organisasi pelaksana dalam mengimplementasikan Jamkesmas. Dari sisi pemberi pelayanan kesehatan, selain 11 rumah sakit yang siap memberikan pelayanan kesehatan kepada masyarakat peserta program Jamkesmas, saat ini ada 27 puskesmas di Bantul. Beberapa puskesmas bahkan sudah memberikan pelayanan 24 jam dan rawat inap. Masing-masing puskesmas juga memiliki dokter gigi, dokter umum, apoteker, bidan, perawat, tenaga klinik laboratorium, serta tenaga administratif.

Dalam pelaksanaan program Jamkesmas di Kabupaten Bantul, PT Askes (Persero) AAM Bantul sebagai salah satu instansi terkait pengelola program selama ini tidak memiliki dana tersendiri untuk pengelolaan program. Demikian juga kantor BKKPP dan KB yang bertugas melakukan pendataan keluarga miskin juga tidak didukung oleh dana tersendiri untuk pengelolaan program tersebut. Bahkan dalam pelaksanaan kerja, SK yang mengatur tentang tugas dan fungsi lembaga terkait pun tidak ada. Yang ada hanya SK Bupati tentang tim koordinasi. Hal tersebut menyebabkan pandangan beberapa pelaksana program dari berbagai instansi merasa mendapatkan tambahan beban kerja di luar tugas pokok mereka dalam lembaganya.

Dari pembahasan tersebut, secara kelembagaan dukungan sarana dan prasarana terhadap penyelenggaraan program Jamkesmas di Kabupaten Bantul cukup memadai, baik dari puskesmas maupun rumah sakit. Walaupun masih ada kendala tidak adanya dukungan dana khusus untuk pelaksanaan program di beberapa instansi terkait pengelola program Jamkesmas. 
Pencapaian hasil akhir (outcomes) kebijakan meliputi beberapa hal berikut. Pertama, penyelenggaraan keuangan yang transparan dan akuntabel dalam program. Peningkatan pelayanan kesehatan selalu diupayakan oleh pemerintah. Demikian juga dalam hal penyelenggaraan keuangan yang transparan dan akuntabel pada pelaksanaan program Jamkesmas. Setelah pada awal pelaksanaan program Jamkesmas menggunakan sistem paket dalam pembayaran klaim, sejak 1 Januari 2009, pemerintah pusat menerapkan sistem Indonesian Diagnosis Related Group (INA-DRG) dalam upaya kendali biaya dan kendali mutu pada seluruh Pemberi Pelayanan Kesehatan (PPK). Kalangan penyedia layanan kesehatan termasuk dokter, apoteker, dan rumah sakit telah mengikuti standar tarif berdasarkan kelompok diagnosis penyakit (Diagnosis Related Groups) yang diharapkan akan mempermudah penyelesaian pembiayaan kesehatan. Dengan demikian berapa dana yang harus dipersiapkan dan kemungkinan dana yang bisa digunakan akan lebih mudah dipertanggungjawabkan. Jika pada pelaksanaan prgram Askeskin pengelolaan atau penyaluran dana dikirim dari Kantor Pusat Kas Negara (KPKN) ke rumah sakit melalui PT Askes (Persero), kemudian pada pelaksanaan Jamkesmas, dana langsung ditransfer KPKN ke rekening rumah sakit.

Walaupun demikian, hal tersebut menurut penilaian beberapa pihak, menambah beban fungsi rumah sakit sebagai penyedia layanan kesehatan sekaligus sebagai pengelola pembiayaan kesehatan. Dari sisi sumber daya manusia pelaksana program, hal tersebut menyebabkan klaim yang diajukan rumah sakit di seluruh Indonesia mengalami tunggakan. Pada SDM pelaksana program di RS Panembahan Senopati hal tersebut menyebabkan para petugas rumah sakit yang menangani dan mengelola program menjadi keteteran. Apalagi kemudian Kementrian Kesehatan pada September 2010 melakukan penggantian program komputerisasi klaim Jamkesmas dari INA-DRG ke Indonesia Case Based Group (INACBG'S). Selain membut keteteran, para petugas yang sudah menguasai software sebelumnya harus mempelajari software baru ini.

Dari pembahasan tersebut, penyelenggaraan dan pengelolaan dana penyelenggaraan keuangan program Jamkesmas sudah dilakukan oleh PPK di Bantul dengan sistem komputerisasi klaim yang sudah memiliki standar, sehingga pengelolaan keuangan bersifat terpusat dan terkendali dan tidak menimbulkan karut marut dalam pelaksanaannya. Walaupun demikian permasalahan keterlambatan pembayaran tunggakan klaim masih dijumpai, bahkan menimbulkan beban petugas pengelola program di rumah sakit karena adanya pergantian software. 
Kedua, peningkatan akses masyarakat miskin terhadap layanan kesehatan. Pada saat ini Jumlah penduduk di Kabupaten Bantul Berdasarkan Sensus Penduduk/ BPS Tahun 2010 Sebesar 910.572 Jiwa. Dari Jumlah tersebut, yang mempunyai jaminan kesehatan sebesar 414.183 jiwa yang terdiri dari Peserta Jamkesmas, Peserta Jamkesos, Peserta Askes PNS dan Peserta Jamsostek, dan jumlah penduduk yang belum mempunyai Jaminan kesehatan sebesar 496.389 Jiwa. Untuk mencapai Universal Coverage di perlukan Upaya pengembangan jaminan kesehatan salah satunya dengan program jaminan Kesehatan Daerah.

Di RSUD Panembahan Senopati, jumlah total jumlah kunjungan rawat inap di tahun 2010 ada 20.155 pasien. Jumlah tersebut meningkat dibandingkan 2009 yang hanya ada 17.673 pasien. Sedang untuk rawat jalan di 2010 ada 164.362 pasien dan tahun 2009 sebanyak 126.847 pasien. Jaminan pelayanan kesehatan bagi penduduk miskin diharapkan akan mampu meningkatkan akses penduduk miskin terhadap pelayanan kesehatan, namun belum sepenuhnya dapat meningkatkan status kesehatan masyarakat miskin akibat fasilitas pelayanan kesehatan dasar yang masih belum memadai terutama untuk daerah tertinggal, terpencil, perbatasan dan kepulauan. Sampai dengan tahun 2008, jumlah rumah sakit yang telah terlibat dalam pelayanan Jamkesmas telah mencapai 70 persen dari jumlah RS, baik RS milik pemerintah maupun swasta.

Selain itu, dengan akan adanya Jaminan Kesehatan Daerah (Jamkesda) di Kabupaten Bantul sangat membantu masyarakat, terutama masyarakat miskin untuk mendapat pelayanan kesehatan. Hal tersebut disampaikan oleh Asisten Bidang Pemerintahan Drs.Misbakhul Munir. Ditambahkan bahwa dengan adanya program pemberian jaminan kepada masyarakat miskin ini bisa meningkatkan mutu pelayanan rumah sakit di Bantul, serta lebih leluasa untuk memberi pelayanan kesehatan masyarakat. Pemda Kabupaten sangat memperhatikan kesehatan masyarakat Bantul dengan selalu menggalakkan program peningkatan kesehatan. Untuk bisa menjangkau masyarakat miskin sebesar 64 ribu orang, Pemda Bantul telah memberikan dana stimulan untuk kesehatan.

Menurut Kepala Dinas Sosial Drs. H. Mahmudi, M. Si, sebagai daerah yang merupakan pemerintahan Empatic Governance, Bantul telah memberikan santunan Jamkesmas, Jamkesos juga akan ada Jamkesda yang dikelola oleh Dinas Kesehatan dan Dinas Sosial. Sampai sekarang ini, penerima Jamkesmas adalah sebanyak 222.987 jiwa. Pemberian santunan tersebut berdasar data dari BPS yang juga benar-benar dilakukan seleksi yang ketat. Dalam setahun bisa menyalurkan dana sebesar Rp 3 miliar kepada 2.400 pemohon. Dana stimulan untuk Jamkesda tersebut berasal dari dana APBD yang disalurkan melalui DAK (dana alokasi khusus). Dalam 
pemberian dana pada tahun 2011 ini, sampai dengan bulan April 2011 sudah disalurkan dana sebesar Rp. 1,3 miliar.

Selain program tersebut, Kabupaten Bantul juga sudah dilaksanakan program Jampersal. Misalnya yang dialami oleh pasangan suami istri Ginanti dan Bayu Setyo Nugroho warga dusun Wintaos, Kirimulyo, Panggang, Gunungkidul. Pada awal bulan Agustus 2011, Ginanti melahirkan bayi laki-laki kembar tiga dan mendapatkan pelayanan secara gratis dari RS Panembahan Senopati. Dikemukakan oleh Gandung Bambang Hermanto, Wakil Direktur Bagian Pelayanan RSUD Panembahan Senopati bahwa biaya melahirkan tersebut ditanggung Jampersal.

Dari pembahasan tersebut, jaminan pelayanan kesehatan bagi penduduk miskin telah mampu meningkatkan akses penduduk miskin terhadap pelayanan kesehatan, walaupun belum sepenuhnya dapat meningkatkan status kesehatan masyarakat miskin. Hal tersebut disebabkan masih adanya program-program jaminan pelayanan kesehatan yang belum dapat dilaksanakan di Kabupaten Bantul karena keterbatasan dana. Namun demikian pemerintah kabupaten Bantul dinilai telah berusaha mengusahakan jaminan pelayanan kesehatan masyarakat miskin misalnya melalui program life saving bagi penduduk miskin dengan lima macam penyakit kronis, melalui mekanisme SKM, dan Jampersal.

\section{Permasalahan-permasalahan yang ada dalam implementasi kebijakan}

Dalam pelaksanaan program Jamkesmas di Kabupaten Bantul, permasalahan pertama yang ditemui di lapangan adalah ketidaktepatan sasaran sebagai peserta program, karena update data sebenarnya sudah dilakukan kabupaten, tetapi di pusat datanya tidak dirubah, padahal penerima program ditetapkan berdasarkan kuota dari pusat. Permasalahan lain yang berkaitan dengan kepesertaan adalah belum semua sasaran program mendapatkan kartu peserta. Kepala Bidang Pengolahan dan Pengelolaan Data dan Pengkajian Kantor BKKPP dan KB, Dra. Lestari Hardyaningsih menjelaskan bahwa luputnya warga miskin masuk program Jamkesmas bisa disebabkan oleh beberapa faktor yaitu mungkin yang bersangkutan adalah warga miskin baru sehingga namanya belum terda ftar dalam Jamkesmas. Karena data yang dijadikan acuan penerima Jamkesmas 2011 menggunakan data sensus BPS tahun 2008. Sehingga bila ada yang belum masuk dalam program, karena pada waktu sensus belum masuk. Selain hal tersebut ada juga warga Bantul yang mendaftarkan diri menjadi warga miskin agar dapat menjadi peserta program Jamkesmas.

Selain itu, pemanfaatan program Jamkesmas oleh masyarakat miskin belum optimal karena masyarakat tidak menyimpan kartunya sebagai syarat mendapatkan pelayanan dari PPK. Masyarakat yang sudah memiliki kartu peserta Jamkesmas juga kadang tidak memiliki 
kelengkapan syarat yang lain, misalnya KTP atau KTPnya sudah tidak berlaku lagi sehingga ketika sakit dan akan mengurus kelengkapan peserta menjadi terhambat.

Pendanaan yang bersifat terpusat menyebabkan keterlambatan pembayaran klaim. Tunggakan klaim Jamkesmas bulan Januari sampai dengan bulan Juni 2011 RSUD Panembahan Senopati mencapai 8,4 miliar. Sedangkan untuk tahun 2010 ada 1,2 miliar yang belum cair dari total klaim sejumlah Rp 15 miliar. Sehingga saat ini baru cair Rp 13,8 miliar, karena bulan Desember 2010 belum cair. Kabag Keuangan RSUD Panembahan Senopati Andriyandono, SE, MM mengatakan, tunggakan tersebut dikarenakan Kementrian Kesehatan pada September 2010 melakukan penggantian program komputerisasi klaim Jamkesmas dari INA-DRG ke INA-CBG'S. Akibatnya klaim yang diajukan rumah sakit di seluruh Indonesia mengalami tunggakan. Bahkan sisa tunggakan di 2010 lalu baru cair bulan Juli 2011.

Meskipun sudah 6 bulan klaim dari RSUD Panembahan Senopati belum terbayar, pihak Rumah sakit menjamin pelayanan bagi peserta Jamkesmas tidak akan terpengaruh atau terhenti. Karena rumah sakit dapat menggunakan dana sisa lebih perhitungan anggaran tahun sebelumnya. Hal ini berbeda dengan kasus yang terjadi di RSUD Sukoharjo karena anggaran jamkesda habis warga miskin harus membayar untuk mendapatkan pelayanan obat dan jasa dokter, yang gratis hanya sarana dan makan selama perawatan (KR, 21 Juli 2011).

Di RSUD Panembahan Senopati, jumlah total jumlah kunjungan rawat inap di tahun 2010 ada 20.155 pasien. Jumlah tersebut meningkat dibandingkan 2009 yang hanya ada 17.673 pasien. Sedang untuk rawat jalan di 2010 ada 164.362 pasien dan tahun 2009 sebanyak 126.847 pasien.

Permasalahan yang lain muncul karena Kabupaten Bantul belum memiliki program Jamkesda bagi warga miskin yang tidak tercakup dalam program Jamkesmas. Padahal daerah lain di DIY seperti Kota Yogyakarta dan Kabupaten Sleman sudah memiliki program Jamkesta/Jamkesda. Sehingga warga Bantul memiliki utang sebesar Rp 730 Juta di RSUD Wirosaban Kota Yogyakarta, dan RS akan menagihnya ke Pemerintah Kabupaten Bantul. Masalah ini mengemuka karena Bantul belum melaksanakan Jamkesda. Jumlah total utang sebesar Rp 730 juta berasal dari sebanyak 310 warga Bantul yang belum melunasi utang mereka di RSUD Kota Wirosaban. Dikemukakan Wakil Direktur Umum dan Keuangan RSUD Kota Jogja Anti Suharyanti, utang tersebut terbagi dua. Pertama, berasal dari kepesertaan Askeskin sebelum adanya Jamkesmas dan Jamkesos pada Januari hingga Agustus 2007. Tagihan obat pasien miskin mencapai Rp 305,8 juta dan bahan habis pakai medis sebesar Rp 181,2 juta, utang peserta Askeskin merupakan tanggung jawab rumah sakit dan pemerintah yang bersangkutan. Sedangkan bagian kedua, berjumlah Rp 243 juta berasal dari masyarakat 
umum yang tidak memiliki jaminan kesehatan. Hal tersebut dapat mengganggu keuangan RSUD Kota Wirosaban, karena jumlahnya yang tidak sedikit. Selain Kabupaten Bantul, sebenarnya Kabupaten Sleman dan Kota Yogyakarta juga memiliki permasalahan yang sama, namun utang tersebut langsung ditalangi oleh Jamkesda. Sedangkan Bantul belum melaksanakan program Jamkesda sehingga agak rumit penyelesaiannya.

Dari pembahasan tersebut, permasalahan yang masih dijumpai dalam pelaksanaan program Jamkesmas terutama adalah dari sisi ketepatan penetapan kelompok sasaran karena data yang tidak diupdate oleh pusat. Selain itu juga kurang optimalnya pemanfaatan program karena pengetahuan masyarakat yang kurang dalam memahami kelengkapan persyaratan untuk mendapatkan pelayanan dari PPK, serta pengelolaan dana terpusat yang menyebabkan keterlambatan pembayaran klain PPK sehingga harus hutang terlebih dahulu.

\section{Kesimpulan dan Saran}

\section{Kesimpulan}

Dari pembahasan tentang pelaksanaan program Jamkesmas di Kabupaten Bantul, dapat diambil kesimpulan secara umum bahwa pelaksanaan program Jamkesmas sudah sesuai dengan mekanisme dan prosedur yang telah ditetapkan, walaupun dalam implementasinya di lapangan masih ditemui berbagai macam permasalahan. Pertama, dalam mekanisme proses penetapan kelompok sasaran sebagai peserta program Jamkesmas sudah mengikuti prosedur yang ditetapkan walaupun di lapangan terkendala data yang tidak diupdate. Sedangkan persyaratan yang harus dipenuhi oleh masyarakat calon peserta, terkadang keadaan yang ditetapkan tidak menunjukan kriteria yang akan diungkap, misalnya kondisi bangunan. Setelah terjadinya gempa di Kabupaten Bantul banyak masyarakat memiliki bangunan permanen karena bantuan.

Kedua, mekanisme penerbitan dan pendistribusian Kartu Peserta oleh PT. Askes (Persero) sudah dilakukan melalui ketentuan yang berlaku. Sedangkan untuk jaminan masyara kat di luar program Jamkesmas, Kabupaten Bantul telah melaksanakan Jamkesos, Jampersal, serta life saving bagi penderita lima macam penyakit kronis, dan penggunaan SKM. Sedangkan Jamkesda baru akan dilaksanakan pada tahun 2012.

Ketiga, Mekanisme peserta program Jamkesmas mendapatkan pelayanan dari PPK baik rumah sakit maupun Puskesmas tidak menemui kendala berarti karena sudah ada SOP yang jelas di RS atau Puskesmas, serta jika masyarakat memiliki persyaratan yang lengkap.

Keempat, Mekanisme dan proses verifikasi klaim PPK sudah dilakukan sesuai ketentuan yang berlaku walaupun sering mengalami keterlambatan karena terbatasnya tenaga verifikasi dan tidak adanya dukungan dana. 
Kelima, Kemampuan organisasi pelaksana kebijakan dapat diandalkan karena sudah melalui pelatihan terlebih dahulu, walaupun pergantian software menyebabkan petugas sedikit keteteran dalam melaksanakan tugasnya. Koordinasi juga dilakukan setiap dua bulan sekali antar pelaksana progam dan $11 \mathrm{RS}$ di Bantul. Sedangkan dukungan sarana dan prasarana yang menunjang pelaksanaan program dari masing-masing lembaga terkait cukup memadai walaupun masih ada kendala karena tidak adanya dana khusus untuk pelaksanaan program Jamkesmas di masing-masing instansi terkait.

Keenam, Pencapaian hasil akhir (outcomes) kebijakan, dalam hal penyelenggaraan keuangan sudah transparan dan akuntabel karena dana bersifat terpusat, walaupun masih terkendala keterlambatan pembayaran klaim. Ada peningkatan akses masyarakat miskin terhadap layanan kesehatan karena pelaksanaan program layanan kesehatan bagi masyarakat miskin di luar program Jamkesmas juga sudah dilakukan di Bantul seperti Jampersal, life saving, mekanisme SKM, dan akan dilaksanakannya Jamkesda.

Ketujuh, Permasalahan-permasalahan yang ada dalam implementasi kebijakan didominasi oleh kendala ketidaktepatan sasaran karena data yang tidak diupdate, kurang optimalnya pemanfaatan program karena pengetahuan masyarakat yang kurang untuk melengkapi persyaratan, dan pengelolaan dana terpusat yang menyebabkan keterlambatan pembayaran kalim.

\section{Saran}

Update data yang sudah disiapkan oleh pemerintah kabupaten setiap tahun hendaknya menjadi pedoman pelaksana di tingkat pusat yaitu Departemen Kesehatan RI dalam penentuan peserta sehingga tepat sasaran. Seharusnya ada juga dukungan dana khusus bagi instansi terkait pelaksana program. Perlu dirumuskan indikator yang lebih akurat untuk menentukan kriteria miskin dan penentuan prosedur baru dalam pengelolaan keuangan yang bersifat komprehensif, menyeluruh dan terpadu mengacu pada UU No. 40 Tahun 2004 tentang SJSN.

\section{Daftar Pustaka}

Agustino, Leo. (2008). Dasar-Dasar Kebijakan Publik. Bandung: Alfabeta.

Bungin, Burhan. ( 2009). Penelitian Kualitatif. Komunikasi, Ekonomi, Kebijakan Publik, dan Ilmu Sosial Lainnya. Jakarta: Kencana.

Dinas Kesehatan Propinsi DIY (2007). Realisasi, Kendala dan Masalah Pelayanan Publik Bidang Kesehatan. Disampaikan dalam Seminar dan Lokakarya Pemetaan Masalah Pelayanan Publik, Yogyakarta, 9 Januari 2007

Goggin, Malcolm L., Ann O'm Bowman, James P. Lester, Laurence J. O’Toole, Jr. (1990). Implementation Theory and Practice Toward a Third Generation.Scott, Forresman/Little, Brown Higher Education A Division of Scott, Forresman and Company Glenview, Illionis, London, England. 
Gulo, W. (2004). Metodologi Penelitian. Jakarta: PT Grasindo.

Islamy, M. Irfan ( 2001). Prinsip-Prinsip Perumusan Kebijakan Negara. Jakarta: Sinar Grafika.

Nugraha, Anselmus Karhendra Oka Tyas ( 2008). Implementasi Program Jamkesmas di Kabupaten Karanganyar. Fakultas Hukum, UNS.

Nugroho, Riant (2008). Public Policy. Teori Kebijakan, Analisis Kebijakan, Proses Kebijakan, Perumusan, Implementasi, Evaluasi, Revisi Risk Management dalam Kebijakan Publik. Jakarta: Elex Media Komputindo.

Putra, Fadilah ( 2003). Partai Politik dan Kebijakan Publik. Yogyakarta: Pustaka Pelajar.

Republik Indonesia. 2008. Keputusan Menteri Kesehatan Nomor 125/Menkes/SK/II/2008 Tentang Pedoman Penyelenggaraan Program Jaminan Kesehatan Masyarakat. Jakarta.

Salim, Agus (2006). Teori dan Paradigma Penelitian Sosial. Buku Sumber untuk Penelitian Kualitatif Ed. Kedua. Yogyakarta: Tiara Wacana.

Silverman, David (2005). Doing Qualitative Research $2^{\text {nd }}$ Edition. SAGE Publications.

Strauss, Anselm dan Corbin, Juliet (2007). Dasar - Dasar Penelitian Kualitatif. Yogyakarta: Pustaka Pelajar.

Suharno. (2010). Dasar-Dasar Kebijakan Publik. Kajian Proses dan Analisis Kebijakan.Yogyakarta: UNY Press.

Surat Keputusan Bupati Bantul No. 137 Tahun 2009 tentang Penetapan Peserta Pengganti Kartu Jamkesmas Kabupaten Bantul 2009

Surat Keputusan Bupati Bantul Nomor 252 tentang Pembentukan Tim Koordinasi Program Jamkesmas Kabupaten Bantul Tahun 2009

Suryabrata, Sumadi (1998). Metodologi Penelitian. Jakarta: PT RajaGrafindo Persada.

Sugiyono (2007). Metode Penelitian Administrasi. Bandung: Alfabeta.

Undang-Undang Dasar 1945.

Undang-Undang Nomor 23 Tahun 1992 Tentang Kesehatan.

Undang-Undang Nomor 40 Tahun 2004 Tentang Sistem Jaminan Sosial Nasional.

Wahab, Solichin Abdul ( 2002). Analisis Kebijaksanaan: dari Formulasi ke Implementasi Kebijaksanaan Negara. Jakarta: SinarGrafika.

Widodo, Erna dan Mokhtar ( 2000). Konstruksi ke Arah Penelitian Deskriptif. Yogyakarta: Avyrouz.

Winarno, Budi (2007). Kebijakan Publik, Teori dan Proses . Yogyakarta: Media Pressindo.

Dari Internet dan Media Massa

Jamkesda Kabupaten Bantul Mempermudah Masyarakat Mendapat Perawatan Kesehatan, (Online), (http://www.bantulkab.go.id/berita/1075.html, diakses tanggal 4 November 2011, pukul 13.00 WIB).

Tentang jamkesmas, (Online), (http://dinkes.jogjaprov.go.id/index.php/cjamkes.html, diakses tanggal 31 Desember 2009, pukul 12.20 WIB).

Tim Pengelola Jamkesmas, (Online),

(http://www.ppjk.depkes.go.id/index.php?option=com_content\&view=article\&id=106:pengo rganisasian\&catid=56\&Itemid=28, diakses tanggal 22 Oktober 2011 Jam 14.00 WIB). 